\title{
Detection of enteric viruses in recreational waters of an urban lagoon in the city of Rio de Janeiro, Brazil
}

\author{
Carmen Baur Vieira', Anna Carolina de Oliveira Mendes², \\ Flávia Ramos Guimarães ${ }^{1}$, Tulio Machado Fumian¹, José Paulo Gagliardi Leite', \\ Ana Maria Coimbra Gaspar², Marize Pereira Miagostovich ${ }^{1 /+}$ \\ ${ }^{1}$ Laboratório de Virologia Comparada e Ambiental ${ }^{2}$ Laboratório de Desenvolvimento Tecnológico em Virologia, \\ Instituto Oswaldo Cruz-Fiocruz, Rio de Janeiro, RJ, Brasil
}

\begin{abstract}
The aim of this study was to determine the occurrences of the group A rotavirus (RVA), norovirus (NoV) and human adenovirus (HAdV) in the surface waters of an urban lagoon (Rodrigo de Freitas Lagoon) in the city of Rio de Janeiro, Brazil. During one year of surveillance, water samples were obtained from the lagoon and other interconnected ecosystems (river and beach). The samples were concentrated using an adsorption-elution method with a negatively charged membrane and tested by qualitative and quantitative polymerase chain reaction assays. RVA was the most prevalent virus detected (24.3\%) with a viral load ranging from $3.0 \times 10^{1}-5.6 \times 10^{4}$ genome copies $/ L$, followed by $\mathrm{NoV}$ $(18.8 \%)$ and HAdV (16.7\%). Considering water samples suitable for bathing, according to Escherichia coli criterion $(<2,000$ most probable number $/ 100 \mathrm{~mL})$, viruses were detected in 50\% (57/114) of them. Physicochemical parameters were also measured and showed possible correlations between turbidity and RVA presence and between $\mathrm{pH}$ and NoV presence. These data demonstrate the importance of considering viral parameters to ensure water quality and the utilisation of these parameters as additional tools for the characterisation of environmental contamination.
\end{abstract}

Key words: group A rotavirus - norovirus - adenovirus - Rodrigo de Freitas Lagoon - recreational water

Water quality and therefore human health, may be significantly affected by the presence of pathogenic microorganisms originating from untreated sewage that are released into surface waters. The microbiological hazards of recreational water include bacteria, protozoa and viruses (Rees et al. 2000), although current waterborne diseases have been increasingly associated with viral contamination (Bosch et al. 2008).

Viruses present in the gastrointestinal tract of both symptomatic and asymptomatic individuals are excreted in the faeces in extremely high concentrations, ranging from $10^{5}-10^{13}$ viral particles per gram of stool (Bosch et al. 2008, Espinosa et al. 2008, Hamza et al. 2009). These particles become contaminants of urban surface waters due to the continuous discharge of domestic sewage (Donovan et al. 2008, Sinclair et al. 2009).

Group A rotavirus (RVA), which is the most important causative factor of acute gastroenteritis in young children and norovirus (NoV), which is a globally significant disease-causing agent, have been associated with waterborne infections in recreational waters (Greenberg \& Estes 2009, Hamza et al. 2009, Patel et al. 2009). Human adenovirus (HAdV) is responsible for a variety of clinical illnesses involving nearly every human organ system and is associated with numerous outbreaks that

Financial support: CNPq/PAPES V (403530/2008-3)

+Corresponding author: marizepm@ioc.fiocruz.br

Received 21 November 2011

Accepted 29 February 2012 have been linked to recreational water exposure (Mena \& Gerba 2009). HAdV has been proposed to be a viral indicator of human faecal water contamination in developed countries (Pina et al. 1998, Bofill-Mas et al. 2006).

The aim of this study was to assess the dissemination of RVA, NoV and HAdV in Rodrigo de Freitas Lagoon, which is an urban lagoon in the city of Rio de Janeiro, Brazil.

Classified as a primary contact water, defined by direct and prolonged contact with individuals during sports or recreational activities, the Lagoon is routinely monitored by the standards set forth by law that promotes environmental restoration and management of the water body (State Institute of Environment - inea.rj.gov. $\mathrm{br} / \mathrm{fma} /$ lagoa-rodrigo-freitas.asp?cat $=75 \&$ subcat $=80$ ).

Further, the lagoon is considered an area of permanent protection (article 463 of the Organic Law of Rio de Janeiro Municipality). However, over the years, a steady inflow of wastewater and solid matter has adversely affected its water quality (Alves et al. 1998). Recently, a remediation project that was intended to reverse this environmental degradation was developed by a private company in partnership with the state government and municipality of Rio de Janeiro (Lagoa Limpa Project lagoalimpa.com.br/default.aspx).

\section{MATERIALS AND METHODS}

Studied area and water samples - Rodrigo de Freitas Lagoon is located between Ipanema Restinga and Leblon in the south of the city of Rio de Janeiro, Brazil, and possesses a water surface area of $2.2 \mathrm{~km}^{2}$, an average depth of $2.8 \mathrm{~m}$, a perimeter of $7.8 \mathrm{~km}$ and an approximate water volume of $6,200,000 \mathrm{~m}^{3}$. It receives water from the Macacos River, wich begins in the At- 
lantic Forest and for $800 \mathrm{~m}$ in length and width ranging from 10-18 $\mathrm{m}$ channel, named Jardim de Allah, it exchanges water with the Atlantic Sea (State Institute of Environment - inea.rj.gov.br/fma/lagoa-rodrigo-freitas. asp?cat $=75 \&$ subcat $=80$ ).

From August 2007-July 2008, a total of 144 surface water samples were collected monthly from 12 specific sites that were established by the Global Positioning System (TREX Legend, Garmin Ltd, Olathe, KS). Ten of them were representative samples of all of the surrounding and central areas of the lagoon and two were representative of interconnected ecosystems: the Macacos River (river water), which flows into the lagoon, and Leblon Beach (seawater), near the outflow of the Jardim de Allah Channel, where water from the lagoon is drained (Fig. 1).

Virus concentration method - Two litre water samples were concentrated by an adsorption-elution method using a negatively charged membrane as previously described (Katayama et al. 2002). Prior to the filtration process, 25 $\mathrm{mL}$ of $2 \mathrm{~mol} / \mathrm{L} \mathrm{MgCl}_{2}$ were added to $2 \mathrm{~L}$ of water.

Spiking experiments - Three experiments were performed in duplicate to evaluate the recovery viral rates from the different types of water that were used for this study (brackish, river and sea water). One millilitre of a $10 \%$ faecal suspension that was prepared in $0.01 \mathrm{~mol} / \mathrm{L}$ Tris $/ \mathrm{HCl} / \mathrm{Ca}^{++} \mathrm{pH} 7.2$ buffer containing $3.27 \times 10^{7}$ genome copies (gc) of RVA and $1.5 \times 10^{7} \mathrm{gc}$ of NoV, respectively, was spiked into $2 \mathrm{~L}$ of water samples. Unseeded samples were used as negative controls to evaluate natural contamination. RVA and NoV were quantified from the unseeded controls and these values were subtracted from the total amount to normalise the results of the seeded samples. The total amounts of both viruses were determined using the quantitative polymerase chain reaction ( $q$ PCR). Part of the stool sample that had been used to spike the sewage samples was used for RNA extraction and quantification along with the concentrated samples. The number of viral particles was determined by adjust-

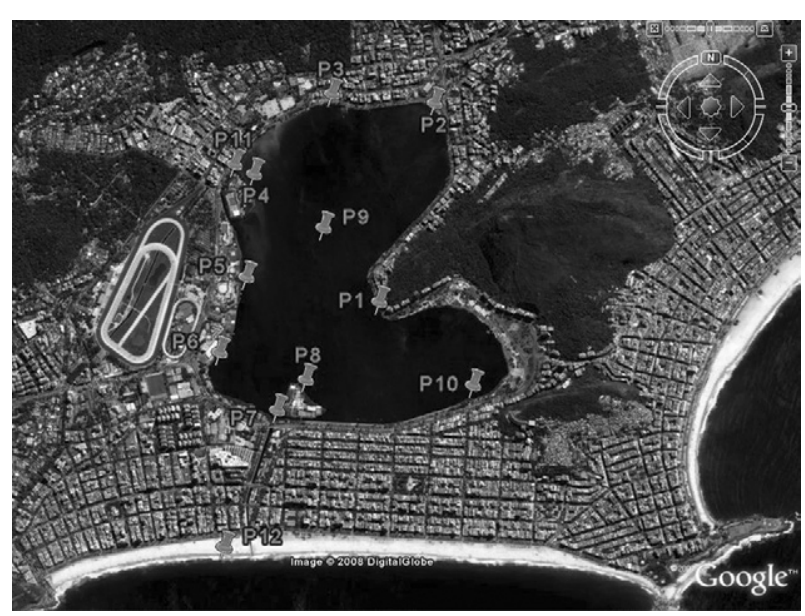

Fig. 1: geographical map of Rodrigo de Freitas Lagoon indicating the water sampling collection sites. P1-10: Rodrigo de Freitas Lagoon; 11: Macacos River; 12: Leblon Beach (Source: Google Earth). ing the values according to the volumes that had been used for each step of the procedure (concentration, extraction, cDNA synthesis and $q \mathrm{PCR}$ reaction). Estimated virus recoveries were calculated as percentages from the numbers of copies of inoculated RVA and NoV.

Virus detection, quantification and molecular characterisation - Nucleic acid extraction was performed using a QIAmp Viral RNA Mini Kit ${ }^{\circledR}$ (Qiagen, Inc, Valencia, California, USA) following the manufacturer's protocol. cDNA was obtained by a reverse transcription reaction using a random primer (PdN6, A260 units, Amersham Biosciences, Chalfont St Giles, Buckinghamshire, UK). The conventional PCR and $q \mathrm{PCR}$ protocols for RVA and NoV detection and molecular characterisation were performed as previously described (Table I). For detecting RVA, VP6 PCR and NSP3 $q$ PCR protocols were carried out in all samples. The VP4 and VP7 protocols were performed only to characterise the positive samples. For the detection of NoV, nested PCR (GI and GII), used as conventional PCR, and ORF1-ORF2 $q \mathrm{PCR}$ were used while the capsid region protocol was performed for sequencing nucleotide characterisation in the positive samples. The HAdV was investigated only by $q$ PCR (Table I). All $q$ PCR protocols were performed with TaqMan Universal PCR Master Mix ${ }^{\circledR}$ (Applied Biosystems, California, USA) in an ABI 7500 ${ }^{\circledR}$ (Applied Biosystems, California, USA). For all molecular procedures, four separated rooms were used to avoid the cross contamination of samples. Milli-Q water and viruses that had been obtained from clinical specimens were used as the negative and positive controls, respectively.

Bacteriological and physicochemical parameters Escherichia coli most probable number (MPN)/100 mL was measured in all water samples using Colilert $^{\circledR}-18$ Quanti-Tray ${ }^{\circledR} / 2000$ Kit (IDEXX Laboratories, Westbrook, EUA) following the manufacturer's recommendations. Temperature $\left({ }^{\circ} \mathrm{C}\right), \mathrm{pH}$, salinity (\%) and turbidity (in nephelometric turbidity units) were measured at the time of collection with the Water Quality Checker (Horiba ${ }^{\circledR}$ U-10, Irvine, CA, EUA).

Statistical analysis - To evaluate the possible correlation between viral detection and bacteriological and physicochemical parameters, a chi-square $(\chi 2)$ test was performed to assess the null hypothesis (homogeneous distribution) of a lack of correlation. Therefore, the rejection of the null hypothesis would not support the presence of either a positive or negative correlation between the parameters. Due to the small number of river and sea water samples, this statistical analysis was performed only in 120 of the brackish water samples.

\section{RESULTS}

Viruses were detected in $51.4 \%(74 / 144)$ of the water samples that were analysed and more than one virus strain was detected in 12 of them. RVA was the most prevalent $(24.3 \%)$, followed by $\mathrm{NoV}(18.8 \%)$ and HAdV $(16.7 \%)$. Table II presents the virus detection data, considering the results that were obtained by both PCR and $q$ PCR. Different rates of viral detection were observed depending on the technique that was used. There was no significant 
difference in RVA between the two methodologies that were applied $(\mathrm{p}=0.088)$. For NoV, only GII was detected by both methods, showing that the greatest rate of detection $(16 \%)$ was observed by PCR $(p=0.0009)$.

Table III presents the virus detection results according to water matrix, revealing the presence of viral contamination in all of them.

The means of the RVA and NoVGII recoveries that were obtained in the spiking experiments were $7.2 \%$ and $5.5 \%$ (brackish water), $2.1 \%$ and $2.9 \%$ (river water) and 2.8 and $1.9 \%$ (seawater), respectively.

Molecular characterisation - All RVA-positive samples from the VP6 PCR and/or NSP3 qPCR were also analysed for the VP4 and VP7 genes by PCR. The genotype $\mathrm{P} 4$ was identified in only one sample. To confirm the RVA strains, seven positive samples were characterised by the partial nucleotide sequencing of the VP6 gene, demonstrating that nucleotide identity ranged from 98.7$99.6 \%$ among samples that were taken from the Rodrigo de Freitas Lagoon. Nucleotide sequences that were obtained in this study were deposited in Genbank/National Center for Biotechnology Information under accession numbers ranging from HQ015464-HQ015470.

For NoVGII, 10 of the 27 positive samples were confirmed by partial capsid protein coding region (region D) amplification.

Bacteriological and physicochemical parameters According to Brazilian regulation (CONAMA 2000), waters that are designated for recreational use are evaluated based on bacteriological parameters, such as E. coli values, and are classified as suitable for bathing when values fall below 2,000 MPN/100 mL, as assessed by monthly sampling (CONAMA 2000). Following this criterion, 95\% $(114 / 120)$ of the brackish water samples (Rodrigo de Freitas Lagoon), $16.7 \%(2 / 12)$ of the river samples (Macacos River) and $83.3 \%(10 / 12)$ of the seawater samples (Leblon Beach) were considered suitable for bathing, with a total of $87.5 \%(126 / 144)$ of the samples showing values below the established limit for this parameter. Fig. 2 presents the mean values of the physicochemical parameters that were obtained from each type of water.

Correlation between virus detection and bacteriological and physicochemical parameters in lagoon water samples - Viruses were detected in 50\% (57/114) of the water samples suitable for bathing according to the $E$. coli criterion (Fig. 3). The statistical analysis demonstrated a homogeneous distribution between the classification of water according to $E$. coli quantification and RVA and NoV detection (RVA: $p>0.1$; NoVGII: $p>0.9$ ), however showed a non-homogeneous distribution with HAdV $(\mathrm{p}<0.01)$. Besides that, it was not possible to conclude whether there was a positive or negative correlation between the elevated levels of $E$. coli and HAdV detection. Based on these data, a statistical analysis of HAdV and RVA and NoVGII detection was performed and showed a non-homogeneous distribution among these viruses $(\mathrm{p}<0.01)$. Neither a positive nor a negative correlation can be established between the detection of HAdV and RVA or NoVGII. Fig. 4 presents the results of positive and negative samples for HAdV in association with RVA and/or NoVGII detection. 
Concerning the physicochemical parameters, nonhomogeneous distributions were observed between turbidity and RVA $(\mathrm{p}<0.05)$ and NoVGII and $\mathrm{pH}(\mathrm{p}<0.01)$. However, it was not possible to establish a correlation between these parameters and viral detection.

\section{DISCUSSION}

The use of water for recreational purposes poses a number of health risks that depend on several factors, such as the characteristics of the water and the immune status of the user (Fong \& Lipp 2005, Espinosa et al. 2008). Epidemiological studies and outbreak reports have demonstrated a relationship between adverse health effects and immersion in recreational water of poor quality, although it is difficult to establish a concrete association between infection and water contact (Pond 2005).

RVA, NoVGII and HAdV detection in the surface waters of the Rodrigo de Freitas Lagoon and its linked ecosystems (river and seawater) revealed their dissemination in water that was considered fit for bathing according to $E$. coli measures that are routinely used to assess the microbiological quality of water (CONAMA 2000). These data corroborate with previous studies that have shown no as- sociation between bacterial indicators and viral contamination (Skraber et al. 2004, Pusch et al. 2005, Rose et al. 2006, Carducci et al. 2008, Espinosa et al. 2009). Because recreational waters are not subjected to any treatment and are considered suitable for swimming at certain bacterial levels, the presence of viruses presents a potential burden to public health that cannot be disregarded.

The high percentage $(50 \%)$ of virus that was detected in the Macacos River that flows into the lagoon reveals that this river is a source of contamination that directly influences the quality of the lagoon water and contributes to the degradation of its ecosystem. The microbiological contamination of the river was also demonstrated by the high percentage of samples $(83.3 \%)$ considered unproper when using E.coli criterion.

With regard to the spread of these viruses to the marine environment (Leblon Beach), it is not possible to rule out whether the contamination is due to the water volume of the lagoon, which is routinely released to maintain the hydrologic balance or to other sources of contamination coming from the beach.

The detection of viruses in different aquatic matrices (brackish water, river and sea water) using the same

TABLE II

Group A rotavirus (RVA), genogroup II norovirus (NoVGII) and human adenovirus (HAdV) distribution according to molecular methods for detection [polymerase chain reaction $(\mathrm{PCR})$ ] and quantification $(q \mathrm{PCR})$

\begin{tabular}{|c|c|c|c|c|c|c|}
\hline \multirow[b]{3}{*}{ Method } & \multicolumn{6}{|c|}{ Virus } \\
\hline & RVA & & NoVGII & & HAdV & \\
\hline & $\begin{array}{c}\text { Positive/studied } \\
\text { n (\%) }\end{array}$ & $\mathrm{gc} / \mathrm{L}$ & $\begin{array}{c}\text { Positive/studied } \\
\text { n (\%) }\end{array}$ & $\mathrm{gc} / \mathrm{L}$ & $\begin{array}{c}\text { Positive/studied } \\
\text { n (\%) }\end{array}$ & $\mathrm{gc} / \mathrm{L}$ \\
\hline PCR & $15 / 144(10.4)$ & - & 23/144 (16) & - & ND & - \\
\hline$q \mathrm{PCR}$ & $25 / 144$ (17.4) & $3.0 \times 10^{1}-5.6 \times 10^{4}$ & $6 / 144(4.2)$ & $1.4-3.2 \times 10^{2}$ & $24 / 144$ (16.7) & $1.2 \times 10^{1}-1.2 \times 10^{3}$ \\
\hline PCR and/or $q \mathrm{PCR}$ & $35 / 144(24.3)^{a}$ & - & $27 / 144(18.8)^{b}$ & - & $24 / 144$ (16.7) & - \\
\hline
\end{tabular}

$a$ : five samples were positive for RVA by PCR and $q$ PCR; $b$ : two samples were positive for NoVGII by PCR and $q$ PCR; gc: genome copies; ND: not done.

TABLE III

Group A rotavirus (RVA), genogroup II norovirus (NoVGII) and human adenovirus (HAdV) detection in the matrices of water samples studied

\begin{tabular}{lcccc}
\hline & & \multicolumn{2}{c}{$\begin{array}{c}\text { Positive/studied } \\
\mathrm{n}(\%)\end{array}$} \\
\cline { 2 - 5 } & RVA & NoVGII & HAdV & Total \\
\hline Brackish water lagoon & $30 / 120(25)$ & $21 / 120(17.5)$ & $20 / 120(16.7)$ & $63 / 120(52.5)^{a}$ \\
River water & $3 / 12(25)$ & $4 / 12(33.3)$ & $2 / 12(16.7)$ & $6 / 12(50)^{b}$ \\
Seawater & $2 / 12(16.7)$ & $2 / 12(16.7)$ & $2 / 12(16.7)$ & $5 / 12(41.7)^{c}$ \\
\hline
\end{tabular}

$a$ : five samples were positive for RVA and HAdV and three samples were positive for RVA and NoVGII; $b$ : one sample was positive for NoVGII and HAdV and two samples were positive for RVA and NoVGII; $c$ : one sample was positive for RVA and HAdV. 
methodology of virus concentration corroborates the usefulness of this negatively charged membrane filtration method for environmental surveys as previously used described for river water, seawater and wastewater (Katayama et al. 2002, Miagostovich et al. 2008, Haramoto et al. 2009, Victoria et al. 2009). Numerous studies have evaluated the recovery of viruses from different water samples and demonstrated that the recovery rate depends not only on concentration and detection methods, but also the source of the environmental water that is tested (Albinana-Gimenez et al. 2009, Haramoto et al. 2009, Victoria et al. 2009).

It is important to emphasise that the detection of high or low levels of virus in a specific geographic area depends not only on virus excretion patterns in the population, but also the protocol that is used for virus detection (Girones et al. 2010). It was observed that there is no statistical significance between PCR and $q$ PCR results in the detection of RVA, although $q$ PCR showed greater sensitivity than PCR. The VP6 sequencing protocol was previously suggested to be more sensitive for RVA detection in environmental samples compared with the amplification of the VP4 and VP7 genes (Ferreira et al. 2009), which also yielded poor results in this study. The P4 genotype, which was the only one that was identified in this study, is thought to be the most prevalent RVA genotype, which has been associated with gastroenteritis cases in Rio de Janeiro in recent years (Leite et al. 2008).

For NoV detection, PCR was more sensitive compared with $q \mathrm{PCR}$, in contrast with previous findings (Victoria et al. 2010). This finding could be explained by the presence of inhibitors in this matrix that could be interfering in this analysis, since inhibitors may interfere with fluorescence detection, independent of their effects on Taq polymerase or RT (Stults et al. 2001). The NoVGII detection results demonstrated a prevalent circulation of this genogroup, according to clinical and environmental studies that were performed in Rio de Janeiro (Victoria et al. 2007, 2010, Ferreira et al. 2008, 2010, Prado et al. 2011).

The analysis of the lagoon waters showed that $95 \%$ of the samples were within the bacterial parameters for bathing that have been established by the Brazilian regulation (CONAMA 2000), although virus was detected in
$50 \%$ of those waters. The percentage of HAdV detected in this study was lower than those observed for RVA and NoV, in accordance with data from other studies (Pusch et al. 2005, Miagostovich et al. 2008), and the statistical analysis did not allow us to point out HAdV as a marker for human viral contamination. As previously mentioned, various studies have suggested HAdV as a viral indicator of human faecal contamination, mainly due to its dissemination in the environment, stability in domestic sewage and environmental samples and resistance to treatment processes that are performed on water and sewage (Puig et al. 1994, Pina et al. 1998, Van Heerden et al. 2003, Pusch et al. 2005, Bofill-Mas et al. 2006). The higher percentage of RVA in the present samples indicates that this virus should be considered as a potential indicator of human faecal contamination in developing countries, as was observed in other studies (Carducci et al. 2006, Miagostovich et al. 2008, Fumian et al. 2011).

In this study, a possible correlation between environmental factors, such as turbidity and $\mathrm{pH}$ and virus presence was demonstrated for RVA and NoV, respectively. RVA and NoV have been detected in various water ma-

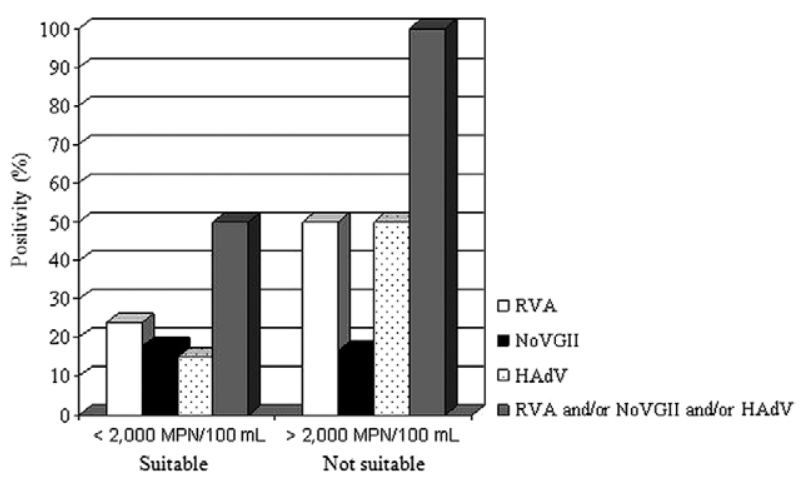

Fig. 3: detection of group A rotavirus (RVA), genogroup II norovirus (NoVGII) and human adenovirus (HAdV) in samples from Rodrigo de Freitas Lagoon in accordance with the characterisation of water as suitable $(\mathrm{n}=114)$ and not suitable $(\mathrm{n}=6)$ for bathing, according to CONAMA (2000). MPN: most probable number.

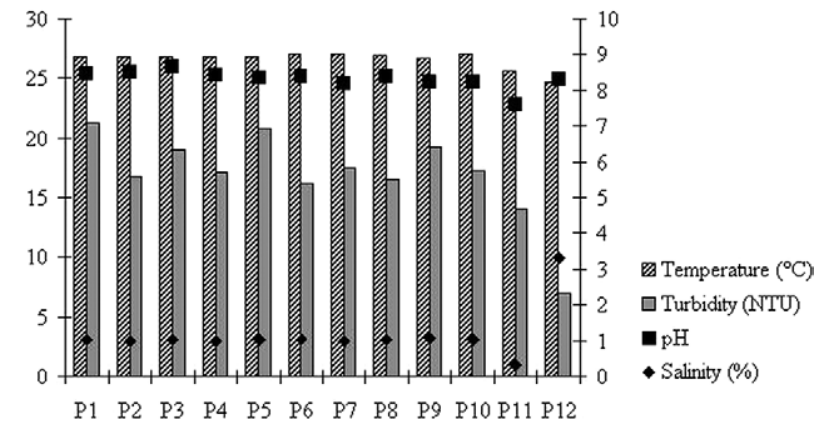

Fig. 2: mean values of physicochemical parameters obtained from each type of water studied. P1-P10: brackish water (Rodrigo de Freitas Lagoon); 11: river water (Macacos River); 12: seawater (Leblon Beach); NTU: nephelometric turbidity units.

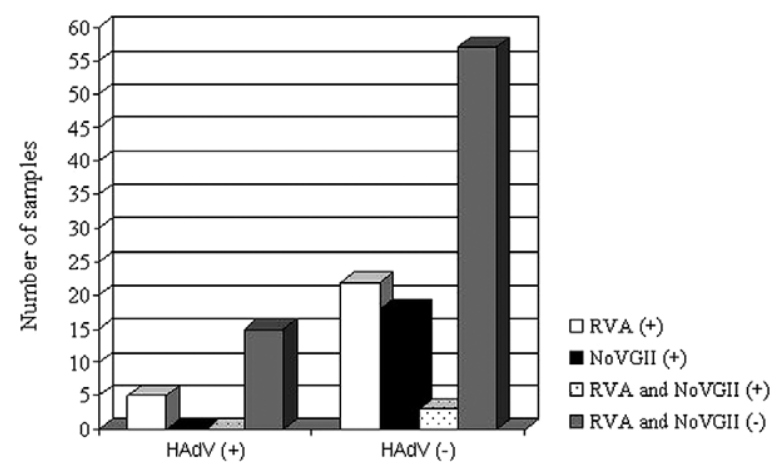

Fig. 4: group A rotavirus (RVA) and genogroup II norovirus (NoVGII) detection according to human adenovirus (HAdV) presence in 120 water samples from Rodrigo de Freitas Lagoon. +: positive; -: negative. 
trices in association with low or high turbidity values, such as drinking water, beaches and pools, sewagecontaminated water and domestic sewage (Lodder et al. 1999, Hafliger et al. 2000, John \& Rose 2005, Podewils et al. 2007, Miagostovich et al. 2008, Ferreira et al. 2009, Hamza et al. 2009, Rutjes et al. 2009, Wong et al. 2009, Victoria et al. 2010). Additionally, it has been demonstrated that $\mathrm{pH}$ influences viral aggregation and susceptibility to virucidal factors in the water, such as chlorine (Pancorbo et al. 1987, Gerba 2007). These parameters, in addition to temperature and other environmental components, such as proteases and RNAses, have been described as factors that can influence the resistance and inactivation of viruses in aquatic environments (Ward et al. 1986, Carter 2005, Fong \& Lipp 2005).

In conclusion, this study demonstrates the spread of enteric viruses in recreational waters that are considered suitable for bathing according to the currently used bacteriological criteria. These results emphasise the importance of assessing the sources of environmental contamination in interconnected ecosystems to effectively enhance the safety of recreational waters and to demonstrate the need to include virological parameters when determining water quality to reduce the potential exposure of users.

\section{ACKNOWLEDGEMENTS}

To PDTIS DNA Sequence Platform staff at Fiocruz, for technical support in sequencing reactions, to Prof. Takumi Iguchi, ENSP-Fiocruz, for the support with the statistical analysis of the data obtained in this study. This research study is under the scope of the activities of Fiocruz as a Collaborating Center of PAHO/WHO of Public and Environmental Health.

\section{REFERENCES}

Albinana-Gimenez N, Clemente-Casares P, Calgua B, Huguet JM, Courtois S, Girones R 2009. Comparison of methods for concentrating human adenoviruses, polyomavirus JC and noroviruses in source waters and drinking water using quantitative PCR. J Virol Methods 158: 104-109.

Alves DTM, Argento MSF, Cruz CBM, Zee D 1998. Qualidade ambiental da lâmina d'água da Lagoa Rodrigo de Freitas - RJ. Subsídios aos estudos de impactos ambientais em lagoas costeiras. In T Krug, BFT Rudorff, UM de Freitas, Proceedings of the 9th Brazilian Symposium of Remote Sensing, INPE, São José dos Campos, p. 79-88.

Bofill-Mas S, Albinana-Gimenez N, Clemente-Casares P, Hundesa A, Rodriguez-Manzano J, Allard A, Calvo M, Girones R 2006. Quantification and stability of human adenoviruses and polyomavirus JCPyV in wastewater matrices. Appl Environ Microbiol 72: 7894-7896.

Bosch A, Guix S, Sano D, Pintó RM 2008. New tools for the study and direct surveillance of viral pathogens in water. Curr Opin Biotechnol 19: 295-301.

Boxman IL, Tilburg JJ, Te Loeke NA, Vennema H, Jonker K, de Boer E, Koopmans M 2006. Detection of noroviruses in shellfish in the Netherlands. Int J Food Microbiol 108: 391-396.

Carducci A, Morici P, Pizzi F, Battistini R, Rovini E, Verani M 2008. Study of the viral removal efficiency in an urban 12 wastewater treatment plant. Water Sci Technol 58: 893-897.

Carducci A, Verani M, Battistini R, Pizzi F, Rovini E, Andreoli E, Casini B 2006. Epidemiological surveillance of human enteric viruses by monitoring of different environmental matrices. $\mathrm{Wa}$ ter Sci Technol 54: 239-244.
Carter MJ 2005. Enterically infecting viruses: pathogenicity, transmission and significance for food and waterborne infection. J Appl Microbiol 98: 1354-1380.

CONAMA - Conselho Nacional do Meio Ambiente 2000. Ministério do Meio Ambiente. Resolução 274 de 29 de novembro de 2000. Diário Oficial da República Federativa do Brasil, Poder Executivo, Brasília, DF.

Das BK, Gentsch JR, Cicirello PHG, Woods A, Gupta A, Ramachandran M, Kumar R, Bhan MK, Glass RI 1994. Characterization of rotavirus strains from newborns in New Delhi, India. $J$ Clin Microbiol 32: 1820-1822.

Donovan E, Unice K, Roberts JD, Harris M, Finley B 2008. Risk of gastrointestinal disease associated with exposure to pathogens in the water of the lower Passaic River. Appl Environ Microbiol 74: 994-1003.

Espinosa AC, Arias CF, Sánchez-Colón S, Mazari-Hiriart M 2009. Comparative study of enteric viruses, coliphages and indicator bacteria for evaluating water quality in a tropical high-altitude system. Environ Health 8: 49.

Espinosa AC, Mazari-Hiriart M, Espinosa R, Maruri-Avidal L, Méndes E, Arias CF 2008. Infectivity and genome persistence of rotavirus and astrovirus in groundwater and surface water. Water Res 42: 2618-2628.

Ferreira FF, Guimarães FR, Fumian TM, Victoria M, Vieira CB, Luz S, Shubo T, Leite JPG, Miagostovich MP 2009. Environmental dissemination of group A rotavirus: P-type, G-type and subgroup characterization. Water Sci Technol 60: 633-642.

Ferreira MS, Victoria M, Carvalho-Costa FA, Vieira CB, Xavier MP, Fioretti JM, Andrade J, Volotão EM, Rocha M, Leite JP, Miagostovich MP 2010. Surveillance of norovirus infections in the state of Rio de Janeiro, Brazil 2005-2008. J Med Virol 82: 1442-1448.

Ferreira MS, Xavier MP, Fumian TM, Victoria M, Oliveira SA, Pena LH, Leite JP, Miagostovich MP 2008. Acute gastroenteritis cases associated with noroviruses infection in the state of Rio de Janeiro. J Med Virol 80: 338-344.

Fischer TK, Steinsland H, Molbak K, Ca R, Gentsch JR, ValentinerBranth P, Aaby P, Sommerfelt H 2000. Genotype profiles of rotavirus strains from children in a suburban community in GuineaBissau, Western Africa. J Clin Microbiol 38: 264-267.

Fong T-T, Lipp EK 2005. Enteric viruses of humans and animals in aquatic environments: health risks, detection and potential water quality assessment tools. Microbiol Molec Biol Rev 69: 357-371.

Fumian TM, Leite JP, Rose TL, Prado T, Miagostovich MP 2011. One year environmental surveillance of rotavirus specie A (RVA) genotypes in circulation after the introduction of the Rotarix ${ }^{\mathbb{B}}$ vaccine in Rio de Janeiro, Brazil. Water Res 45: 5755-5763.

Gentsch JR, Glass RI, Woods P, Gouvea V, Gorziglia M, Flores J, Das BK, Bhan MK 1992. Identification of group A rotavirus gene 4 types by polymerase chain reaction. J Clin Microbiol 30: $1365-1373$.

Gerba CP 2007. Virus occurrence and survival in the environmental waters. In A Bosch, Human viruses in water, 2nd ed., Vol. xvii, Elsevier, Oxford, p. 91-108.

Girones R, Ferrús MA, Alonso JL, Rodriguez-Manzano J, Calgua B, Corrêa AdeA, Hundesa A, Carratala A, Bofill-Mas S 2010. Molecular detection of pathogens in water - the pros and cons of molecular techniques. Water Res 44: 4325-4339.

Gouvea V, Santos N, Timenetsky M do C 1994. Identification of bovine and porcine rotavirus G types by PCR. J Clin Microbiol 32: 1338-1340.

Greenberg HB, Estes MK 2009. Rotavirus: from pathogenesis to vaccination. Gastroenterology 136: 1939-1951. 
Hafliger D, Hubner PH, Luthy J 2000. Outbreak of viral gastroenteritis due to sewage-contaminated drinking water. Intern J Food Microbiol 54: 123-126.

Hamza IA, Jurzik L, Stang A, Sure K, Uberla K, Wilhelm M 2009. Detection of human viruses in rivers of a densely-populated area in Germany using a virus adsorption elution method optimized for PCR analyses. Water Res 43: 2657-2668.

Haramoto E, Katayama H, Utagawa E, Ohgaki S 2009. Recovery of human norovirus from water by virus concentration methods. J Virol Methods 160: 206-209.

Heim A, Ebnet C, Harste G, Pring-Akerblom P 2003. Rapid and quantitative detection of human adenovirus DNA by real-time PCR. J Med Virol 70: 228-239.

Iturriza-Gomara M, Wong C, Blome S, Desselberger U, Gray J 2002. Molecular characterization of VP6 genes of human rotavirus isolates: correlation of genogroups with subgroups and evidence of independent segregation. J Virol 76: 6596-6601.

John DE, Rose JB 2005. Review of factors affecting microbial survival in groundwater. Environ Sci Technol 39: 7345-7356.

Kageyama, T, Kojima S, Shinohara M, Uchida K, Fukushi S, Hoshino FB, Takeda N, Katayama K 2003. Broadly reactive and highly sensitive assay for norwalk-like viruses based on real-time quantitative reverse transcription-PCR. J Clin Microbiol 41: 1548-1557.

Katayama H, Shimasaki A, Ohgaki S 2002. Development of a virus concentration method and its application to detection of enterovirus and norwalk virus from coastal seawater. Appl Environ Microbiol 68: 1033-1039.

Leite JPG, Carvalho-Costa FA, Linhares AC 2008. Group A rotavirus genotypes and the ongoing Brazilian experience - A Review. Mem Inst Oswaldo Cruz 103: 745-753.

Lodder WJ, Vinjé J, Heide Rvande, de Roda Husman AM, Leenen EJ, Koopmans MP 1999. Molecular detection of norwalk-like calicivirus in sewage. Appl Environ Microbiol 65: 5624-5627.

Mena KD, Gerba CP 2009. Waterborne adenovirus. In DM Whitacre, Reviews of environmental contamination and toxicology, Springer, New York, p. 133-167.

Miagostovich MP, Ferreira FF, Guimarães FR, Fumian TM, DinizMendes L, Luz SL, Silva LA, Leite JP 2008. Molecular detection and characterization of gastroenteritis viruses occurring naturally in the stream waters of Manaus, Central Amazonia, Brazil. Appl Environ Microbiol 74: 375-382.

Pancorbo OC, Evanshen BG, Campbell WF, Lambert S, Curtis SK, Woolley TW 1987. Infectivity and antigenicity reduction rates of human rotavirus strain Wa in fresh waters. Appl Environ Microbiol 53: 1803-1811.

Patel MM, Hall AJ, Vinjé J, Parashar UD 2009. Noroviruses: a comprehensive review. J Clin Virol 44: 1-8.

Pina S, Puig M, Lucena F, Jofre J, Girones R 1998. Viral pollution in the environment and in shellfish: human 11 adenovirus detection by PCR as an index of human viruses. Appl Environ Microbiol 64: $3376-3382$

Podewils LJ, Zanardi Blevins L, Hagenbuch M, Itani D, Burns A, Otto C, Blanton L, Adams S, Monroe SS, Beach MJ, Widdowson M 2007. Outbreak of norovirus illness associated with a swimming pool. Epidemiol Infect 135: 827-833.

Pond K 2005. Water recreation and disease. Plausibility of associated infections: acute effects, sequelae and mortality, 1st ed., WHO/ IWA, London, $239 \mathrm{pp}$.

Prado T, Silva DM, Guilayn WC, Rose TL, Gaspar AM, Miagostovich MP 2011. Quantification and molecular characterization of en- teric viruses detected in effluents from two hospital wastewater treatment plants. Water Res 45: 1287-1297.

Puig M, Jofre J, Lucena F, Allard A, Wadell G, Girones 1994. Detection of adenoviruses and enteroviruses in polluted waters by nested PCR amplification. Appl Environ Microbiol 60: 2963-2970.

Pusch D, Oh DY, Wolf S, Dumke R, Schröter-Bobsin U, Höhne M, Röske I, Schreier E 2005. Detection of enteric viruses and bacterial indicators in German environmental waters. Arch Virol 150: 929-947.

Rees G, Bartram J, Pond K, Goyet S 2000. Introduction. In J Bartram, G Rees, Monitoring bathing waters - A practical guide to the design and implementation of assessments and monitoring programmes, 1st ed., E\&FN Spon, London, 337 pp.

Rose MA, Dhar AK, Brooks HA, Zecchini F, Gersberg RM 2006. Quantitation of hepatitis A virus and enterovirus levels in the lagoon canals and Lido beach of Venice, Italy, using real-time PCR. Water Res 40: 2387-2396.

Rutjes SA, Lodder WJ, van Leeuwen AD, de Roda Husman AM 2009. Detection of infectious rotavirus in naturally contaminated source waters for drinking water production. $J$ Appl Microbiol 107: 97-105.

Sinclair RS, Jones EL, Gerba CP 2009. Viruses in recreational water-borne disease outbreaks: a review. J Appl Microbiol 107: 1769-1780.

Skraber S, Gassiolloud B, Schwartzbrod L, Gantzer C 2004. Survival of infectious Poliovirus-1 in river water compared to the persistence of somatic coliphages, thermotolerant coliforms and poiliovirus-1 genome. Water Res 38: 2927-2933.

Stults JR, Snoeyenbos-West O, Methe B, Lovley DR, Chandler DP 2001. Application of the 5' fluorogenic exonuclease assay (TaqMan) for quantitative ribosomal DNA and rRNA analysis in sediments. Appl Environ Microbiol 67: 2781-2789.

Van Heerden J, Ehlers MM, Van Zyl WB, Grabow WO 2003. Incidence of adenoviruses in raw and treated water. Water Res 37 : 3704-3708.

Victoria M, Carvalho-Costa FA, Heinemann MB, Leite JP, Miagostovich M 2007. Prevalence and molecular epidemiology of noroviruses in hospitalized children with acute gastroenteritis in Rio de Janeiro, Brazil, 2004. Ped Infect Dis J 26: 602-606.

Victoria M, Guimarães F, Fumian T, Ferreira F, Vieira C, Leite JP, Miagostovich M 2009. Evaluation of an adsorption-elution method for detection of astrovirus and norovirus in environmental waters. J Virol Methods 156: 73-76.

Victoria M, Guimarães FR, Fumian TM, Ferreira FF, Vieira CB, Shubo T, Leite JP, Miagostovich MP 2010. One year monitoring of norovirus in a sewage treatment plant in Rio de Janeiro, Brazil. $J$ Water Health 8: 158-165.

Vinjé J, Hamidjaja RA, Sobsey MD 2004. Development and application of a capsid VP1 (region D) based reverse transcription PCR assay for genotyping of genogroup I and II noroviruses. $J$ Virol Methods 116: 109-117.

Ward RL, Knowlton DR, Winston PE 1986. Mechanism of inactivation of enteric viruses in fresh water. Appl Environ Microbiol 52: 450-459.

Wong M, Kumar L, Jenkins TM, Xagoraraki I, Phanikumar MS, Rose JB 2009. Evaluation of public health risks at recreational beaches in Lake Michigan via detection of enteric viruses and a humanspecific bacteriological marker. Water Res 43: 1137-1149.

Zeng SQ, Halkosalo A, Salminen M, Szakal ED, Puustinen L, Vesikari T 2008. One-step quantitative RT-PCR for the detection of rotavirus in acute gastroenteritis. $J$ Virol Methods 153: 238-240. 